\title{
MATHEMATICAL ASSOCIATION.
}

\section{REPORT OF COUNCIL FOR THE YEAR 1898, PRESENTED AT THE $A N N U A L$ MEETING, 21st JANUARY, 1899.}

The Council have met three times since the last annual meeting, namely, on 6th May, 1898, 23rd September, 1898, and 21 st January, 1899.

Twenty-three new members of the Association have been elected by the Council.

By the deaths of Mr. H. Perigal and Mr. Walter Wren, the Association has lost two members who were each of twenty-five years' standing.

General Meetings of the Association were held at University College, London, on 15th January, 6th May, and 23rd September, 1898, at which the undermentioned papers were read:

"Some Curiosities of Division," by E. M. Langley, M.A.

"A Class of Algebraic Functions," by Prof. H. W. Lloyd Tanner, M.A.

"Construction of a Conic through any five points," by E. Budden, M.A.

"On the Connection between the Inscribed and Escribed Circles of a Triangle," by H. B. Billups, B.A.

"On the Circular Measure of Angles," by Prof. A. C. Dixon, Sc.D.

"A Transformation in Elementary Geometry," by C. E. MVicker, M.A.

"On the Geometrical Treatment of Uniformly Accelerated Motion," by W. J. Dobbs, M.A.

"A Theorem in Infinitesimals," by C. E. MVicker, M.A.

"On the Curves which cut a System of Coaxal Circles at a Constant Angle," by Prof. A. Lodge, M.A.

Miscellaneous Notes, by Prof. A. Lodge, M.A., G. Heppel, M.A., F. S. Macaulay, D.Sc., and others.

It is very satisfactory to find that these meetings are gradually becoming better attended. It is hoped that members will carefully note the date of the meetings, which are always announced on the front page of the cover of the Gazette.

The Council have to announce with great regret, that Dr. F. S. Macaulay has, through pressure of other duties, been obliged to retire from the Editorship of the Gazette, but they are glad to be able also to announce that Mr. W. J. Greenstreet, Headmaster of Marling School, Stroud, has kindly undertaken the onerous duties, for which, by his wide reading, he is preeminently fitted. The Council desire to record their hearty thanks to Dr. Macaulay for his past successful labours, and also to the other members of the editorial staff who have ably assisted him.

Prof. A. Lodge, who has presided over the Association for the last two years, now retires under Rule 7 , and the Council have very great pleasure in announcing that, in response to their invitation, Professor Sir Robert S. Ball, LL.D., F.R.S., has consented to succeed him. 


\title{
THE MATHEMATICAL ASSOCIATION.
}

\section{(An Association of Teachers and Students of Elementary Mathematics.)}

\author{
fresident: \\ Professor Sir Robert S. BaLl, LL.D., F.R.S. \\ gice-19residents : \\ R. B. HaYward, M.A., F.R.S. \\ J. LARMOR, D.Sc., F.R.S. \\ R. Levett, M.A. \\ Professor A. Lodge, M.A. \\ Professor G. M. Minchis, M.A., F.R.S.
}

\section{Treagurer :}

Rev. J. J. Mrune, M.A., Seafield Technical College, Crofton, Hants.

EDitor of the Mathematical Gazette:

W. J. Greenstreet, M.A., Marling Endowed School, Stroud.

\section{Serretaries :}

C. Prendebury, M.A., St. Paul's School, London, W.

S. O. Roberts, M.A., Merchant Taylor's' School, London, E.C.

\section{(D)ther Attembers of the council :}

J. M. Dyer, M.A.

H. D. Ellis, M.A.

Professor R. W. Genese, M.A.

Miss F. Hardcastle.

G. Heppei, M.A.
Prof. W. H. H. Hudson, M.A.

F. S. Macaulay, M.A., D.Sc.

C. E. M'Vicker, M.A.

Miss M. T. Meyer.

Prof. H. W. Lloyd Tanner.

The Mathematical Association, until recently known as the Association for the Improvement of Geometrical Teaching, is intended not only to promote the special object for which it was originally founded, but to bring within its purview all branches of elementary mathematics.

Its fundamental aim as now constituted is to make itself a strong combination of all mathematical masters and mistresses, in primary as well as secondary schools, who are interested in promoting good methods of teaching. Such an Association would become a recognized authority in its own department, and would exert an important influence on methods of examination.

General Meetings of the Association will be held in London at least once a term, and in other places if desired. At these Meetings papers on elementary mathematics will be read, and any member will be at liberty to propose any motion, or introduce any topic of discussion, subject to the approval of the Council.

Intending members are requested to communicate with one of the Secretaries. The subscription to the Association is $7 \mathrm{~s}$. 6d. per annum, and is due on Jan. 1st. It includes the subscription to the Gazette. 